\title{
Autologous Rosette-forming T Cells as the Responding Cells in Human Autologous Mixed-Lymphocyte Reaction
}

\author{
Ronald Palacios, luis Llorente, Donato Alarcón-Segovia, \\ Alejandro Ruiz-Arguelles, and Efraín Diaz-Jouanen, Department of \\ Immunology and Rheumatology, Instituto Nacional de la Nutrición, México \\ 22, D. F., México
}

A в S T R A C T Autologous rosette-forming cells ( $\mathrm{T}$ ar cells) have surface and functional characteristics of post-thymic precursors and among these characteristics there are some that have been identified in the responsive cell of the autologous mixed-lymphocyte reaction (AMLR). We therefore did AMLR with circulating mononuclear cells from normal subjects using as responding cells either total $\mathrm{T}$ cells, $\mathrm{T}$ cells depleted of $\mathrm{T}$ ar cells, or purified Tar cells.

The response of Tar cells in AMLR was significantly greater than that of total $\mathrm{T}$ cells and these responded significantly more than Tar-depleted $\mathrm{T}$ cells. Conversely, Tar cells responded less than total $\mathrm{T}$ cells or $\mathrm{T}$ cells depleted of Tar cells in allogeneic mixedlymphocyte reactions.

Increasing numbers of $\mathrm{T}$ ar cells gave significantly greater AMLR responses both alone and when added to diminishing proportions of Tar-depleted $\mathrm{T}$ cells to keep the number of $\mathrm{T}$ cells constant in the system.

Tar cells are the responding cells in AMLR but not in allogeneic mixed-lymphocyte reactions.

\section{INTRODUCTION}

Normally there is autoreactivity between subpopulations of lymphocytes. T lymphocytes respond to autologous non-T lymphocytes in coculture by proliferating (1). This phenomenon has been termed autologous mixed-lymphocyte reaction (AMLR) ${ }^{1}$ and is impaired in the circulating mononuclear cells (MNC) from patients with systemic lupus erythematosus $(2,3)$.

We have recently determined that autologous rosette-

\footnotetext{
Address reprint requests to Dr. Donato Alarcón-Segovia.

Received for publication 10 March 1980 and in revised form 31 March 1980.

'Abbreviations used in this paper: AMLR, autologous mixed-lymphocyte reaction; MEM, minimum essential medium; MNC, peripheral blood mononuclear cells; Tar, autologous rosette-forming $\mathrm{T}$ cells; $\mathrm{T}$-T $a r$, $\mathrm{T}$ cells depleted of Tar cells; SI, stimulation index.
}

forming $\mathrm{T}$ cells (Tar cells) have surface and functional characteristics of post-thymic precursors. ${ }^{2}$ Among these characteristics there are several that have also been found to be those of the responding cells in AMLR (4-11). In this study we tested the role of Tar cells in AMLR and allogeneic mixedlymphocyte reaction using MNC from young healthy adults and found them to be essential for the blastogenic response in AMLR but not in allogeneic mixedlymphocyte response.

\section{METHODS}

Cells separation and identification. We obtained peripheral blood circulating MNC from healthy volunteers whose age ranged from 21 to $36 \mathrm{yr}$. We separated $\mathrm{MNC}$ in Ficoll-Hypaque (Pharmacia, Uppsala-Winthrop de México, Mexico City) gradients as described (12). From them we separated T cells and non-T cells also as described (12). Briefly, we incubated MNC with sheep erythrocytes (SRBC) at a ratio of $1: 70$, at $37^{\circ} \mathrm{C}$ for $15 \mathrm{~min}$, spun them at $1,200 \mathrm{rpm}$ for 10 min, and incubated them at $4^{\circ} \mathrm{C}$ for $18 \mathrm{~h}$. We then relayered the cells' mixture on Ficoll-Hypaque, centrifuged at 1,400 $\mathrm{rpm}$ at $4^{\circ} \mathrm{C}$ for $30 \mathrm{~min}$, and separately collected the rosetted cells in the pellet (total $T$ cells) and the unrosetted cells at the interface (non-T cells). We lysed the SRBC-rosetting with total $\mathrm{T}$ cells by hypotonic shock. Total $\mathrm{T}$ cells included $\geq 94 \%$ SRBC-rosetting cells, $<2 \%$ immunoglobin-bearing cells identified with fluorescein-labeled $\mathbf{F}\left(\mathrm{ab}^{\prime}\right)_{2}$ fragments of goat anti-human immunoglobulins serum (N. L. Cappel Laboratories Inc., Cochranville, Pa.), and $<2 \%$ nonspecific esterase-positive monocytes (13). Non-T cells included $\geq 76 \%$ immunoglobin-bearing cells, $\leq 12 \%$ monocytes, and $<1 \% \mathrm{~T}$ cells. We identified T ar cells as described. ${ }^{2}$ Briefly, we placed $2 \times 10^{6} \mathrm{MNC}$ in $0.2 \mathrm{ml}$ of minimum essential medium (MEM) (Gibco Laboratories, Grand Island Biological Co., Grand Island, N. Y.) and $0.05 \mathrm{ml}$ of autologous serum diluted 1:5 in MEM and incubated them, $30 \mathrm{~min}$ at $4^{\circ} \mathrm{C}$. We then added $16 \times 10^{6}$ autologous erythrocytes obtained from the same heparinized blood sample and washed thrice with phosphate-

\footnotetext{
${ }^{2}$ Palacios, R., D. Alarcón-Segovia, L. Llorente, A. RuízArguelles, and E. Díaz-Jouanen. Human postthymic precursor cells in health and disease. I. Characterization of the autologous rosette-forming $\mathrm{T}$ cells as postthymic precursors. Submitted for publication.
} 
buffered saline and resuspended in $0.8 \mathrm{ml}$ of MEM. We centrifuged the cells' mixture $5 \mathrm{~min}$ at $1,000 \mathrm{rpm}$ and incubated it overnight at $4^{\circ} \mathrm{C}$. We resuspended the cells gently with Pasteur pipettes for either counting the Tar cells or for their separation on Ficoll-Hypaque gradients. For counting we placed the cells mixture on a hemocytometer Neubauer chamber and counted 300 lymphocytes. We counted as Tar cells those lymphocytes forming rosettes with three or more autologous erythrocytes. For separation we centrifuged the cells resuspended in cold MEM on FicollHypaque cushions at $4^{\circ} \mathrm{C}, 1,400 \mathrm{rpm}$ for $30 \mathrm{~min}$. We collected the rosetted cells in the pellet, resuspended them again in cold MEM, and repeated the Ficoll-Hypaque gradient separation at $4^{\circ} \mathrm{C}, 1,400 \mathrm{rpm}$ for $30 \mathrm{~min}$. We then resuspended the rosetted cells in the bottom in warm $\left(37^{\circ} \mathrm{C}\right) \mathrm{MEM}$, incubated them $20 \mathrm{~min}$ at $37^{\circ} \mathrm{C}$, and placed them on warm FicollHypaque and centrifuged them at 1,200 rpm for $20 \mathrm{~min}$ to rid them of the autologous erythrocytes. The Tar cells obtained had $\geq 94 \%$ autologous rosette-forming cells, $<4 \% \mathrm{~T} \mu$ cells, identified by their rosetting with immunoglobin (Ig)M coated ox erythrocytes, ${ }^{2}<1 \% \mathrm{~T} \gamma$ cells, identified by rosetting with IgG coated ox erythrocytes (14), and $<1 \%$ monocytes as identified morphologically and by nonspecific esterase staining.

We depleted total $\mathrm{T}$ cells from $\mathrm{T}$ ar cells by rosetting them with autologous erythrocytes and repeating the above procedure of gradient separation but collecting the nonrosetting $\mathrm{T}$ cells at the interphase ( $\mathrm{T}-\mathrm{T}$ ar cells). Total $\mathrm{T}$ cells included $30.8 \pm 3.5 \%$ T ar cells, whereas T-Tar cells had $<2 \%$ Tar cells.

Autologous and allogeneic mixed-lymphocyte cultures. We incubated the separated MNC subpopulations overnight in $\mathrm{MEM}$ with $20 \%$ pooled normal human serum at $37^{\circ} \mathrm{C}$ in a $5 \% \mathrm{CO}_{2}, 100 \%$ humidity atmosphere. We established mixed-lymphocyte cultures in triplicate, placing $1 \times 10^{5}$ of the separated $\mathrm{T}$ cell subpopulations as responding cells in $0.1 \mathrm{ml}$ of MEM enriched with $20 \%$ pooled, heat-inactivated normal human serum, $0.8 \mathrm{mg}$ L-glutamine (Sigma Chemical Co., St. Louis, Mo.), and $10 \mu \mathrm{g} / \mathrm{ml}$ of gentamicin (Schering Corp., Kenilworth, N. J.) and $1 \times 10^{5}$ of autologous or allogeneic stimulator non-T cells pretreated with $3 \mu \mathrm{g}$ of mitomycin C (Sigma Chemical Co.) per $1 \times 10^{6}$ cells during $30 \mathrm{~min}$ at $37^{\circ} \mathrm{C}$ in a $5 \% \mathrm{CO}_{2}, 100 \%$ humidity chamber. After this, we washed them thrice with MEM and resuspended in enriched MEM at a concentration of $1 \times 10^{6} / \mathrm{ml}$. All cultures were done in culture plates with flat-bottom wells (Costar, Data Packaging, Cambridge, Mass.).

Isolated $\mathrm{T}$ cell subpopulation used as responding cells were placed in the same numbers and conditions unless otherwise indicated. We incubated all cultures $144 \mathrm{~h}$ at $37^{\circ} \mathrm{C}$ in a $5 \% \mathrm{CO}_{2}, 100 \%$ humidity environment. $20 \mathrm{~h}$ before the termination of the incubation period we added $0.5 \mu \mathrm{Ci}$ of [ methyl ${ }^{3} \mathrm{H}$ ] thymidine (New England Nuclear, Boston, Mass.). At the end of the incubation period we harvested the cells in a multiple sample harvester, placed them in a standard scintillation mixture (New England Nuclear) and counted their thymidine incorporation in a liquid scintillation counter (Packard Instrument Co., Downers Grove, Ill.).

Results are reported as $\Delta$ counts per minute. (The difference of the counts per minute from cultures containing both responding and stimulator cells minus the counts per minute from cultures containing responding cells only). We also present them as stimulation indices (SI), which represent the ratio of the mean counts per minute in stimulated cultures over the mean counts per minute in unstimulated cultures.

Statistical analysis. Significance of our results was determined by paired Student's $t$ test (two tailed) and by $\mathrm{F}$ variance test.

\section{RESULTS}

When we placed T-Tar cells as responding cells in the AMLR the response was significantly lower than that obtained when we placed total $\mathrm{T}$ cells. Conversely, when we placed isolated Tar cells, the response was significantly higher than that obtained with either total $\mathrm{T}$ cells or $\mathrm{T}-\mathrm{T}$ ar cells.

In Table I we present the results of individual experiments and of their means, expressed both as $\Delta$ counts per minute as well as by their SI.

Gradual increase in the number of $T$ ar cells placed as responding cells in the AMLR resulted in increase of the response obtained in the AMLR. These results were highly significant statistically with a $99 \%$ level of confidence in a $\mathrm{F}$ variance test (Fig. 1).

When we changed the proportion of Tar cells and

TABLE I

Tar Cells as Responding Cells in AMLR. Results of Individual Experiments and Their Means.

\begin{tabular}{|c|c|c|c|c|c|c|c|}
\hline \multirow[b]{3}{*}{$\begin{array}{c}\text { Experiment } \\
\text { No. }\end{array}$} & \multirow[b]{3}{*}{$\begin{array}{l}\text { Stimulator } \\
\text { cells }\end{array}$} & \multicolumn{6}{|c|}{ Responding cells } \\
\hline & & \multicolumn{2}{|c|}{ Total T } & \multicolumn{2}{|c|}{ T-Tar } & \multicolumn{2}{|c|}{ Tar } \\
\hline & & $\Delta \mathrm{cpm}$ & $\mathrm{SI}^{*}$ & $\Delta \mathrm{cpm}$ & SI & $\Delta \mathrm{cpm}$ & SI \\
\hline 1 & non-T cells & 3,229 & 7.68 & 860 & 1.5 & 7,640 & 18.1 \\
\hline 2 & non-T cells & 2,892 & 8.35 & 678 & 1.4 & 4,654 & 13.4 \\
\hline 3 & non-T cells & 2,710 & 7.97 & 936 & 1.9 & 4,503 & 13.2 \\
\hline 4 & non-T cells & 2,525 & 6.97 & 741 & 1.6 & 5,141 & 14.2 \\
\hline 5 & non-T cells & 3,548 & 10.60 & 987 & 2.1 & 5,372 & 16.0 \\
\hline 6 & non-T cells & 3,140 & 7.65 & 796 & 1.8 & 4,962 & 12.3 \\
\hline mean $\pm S E M^{*}$ & & $3,067 \pm 157$ & $8.2 \pm 0.5$ & $833 \pm 48$ & $1.7 \pm 0.1$ & $5,379 \pm 472$ & $14.5 \pm 0.8$ \\
\hline
\end{tabular}

* All differences significant at the $P<0.0005$ level, paired Student's $t$ test. 


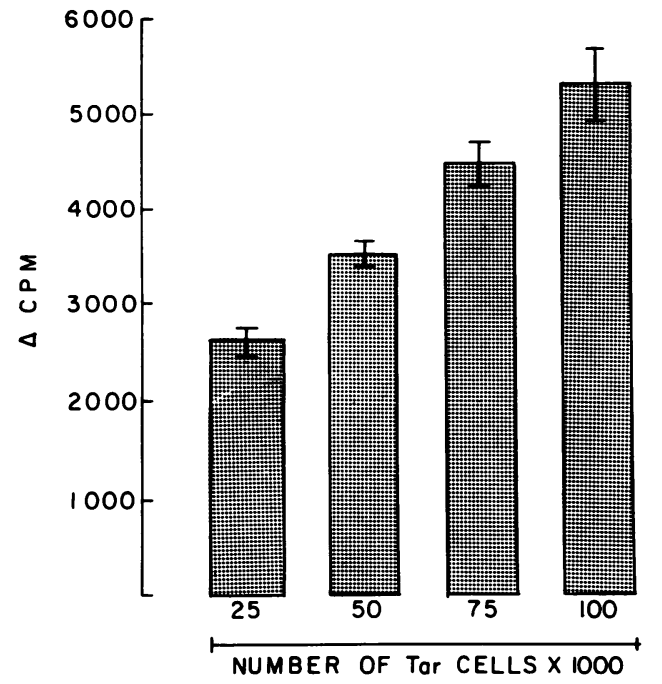

FIgURE 1 Blastogenic response in AMLR of increasing numbers of isolated Tar cells (mean \pm SEM of six experiments).

T-T ar cells in the AMLR we found increased responses as we increased the proportion of Tar cells despite both the simultaneous decrease of T-Tar cells and the keeping of a constant number of "responding" cells (Fig. 2). The results were also highly significant statistically at a $99 \%$ confidence level in a $\mathrm{F}$ variance test.

We found that T-Tar cells gave significantly higher responses in allogeneic mixed lymphocyte reaction than did total $\mathrm{T}$ cells or Tar cells (SI, mean of six experiments \pm SEM, T-T ar cells: $12.5 \pm 2.5$, total $\mathrm{T}$ cells: $9.5 \pm 1.5$, Tar cells: $3.7 \pm 1.0$; all differences $P<0.005$ ).

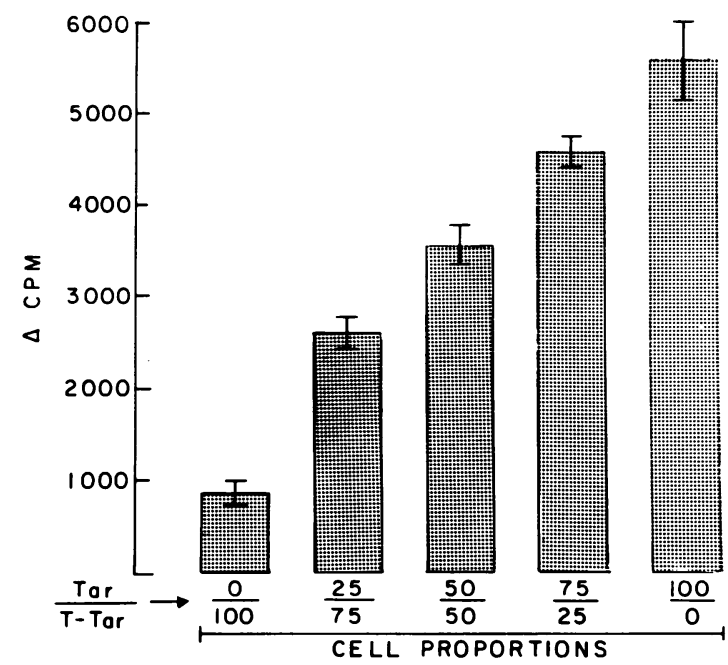

Figure 2 Effect of variations in the proportion of Tar/T-Tar responding cells in the blastogenic response in AMLR. The number of responding and stimulator (non- $\mathrm{T})$ cells remained constant $\left(1 \times 10^{5}\right)$ (mean \pm SEM of six experiments).
Thus the responding cells in AMLR seem to be different from those responding in allogeneic mixedlymphocyte reaction.

\section{DISCUSSION}

We have previously characterized Tar cells as postthymic precursors. ${ }^{2}$ These medium-sized lymphocytes adhere to nylon wool, are theophylline resistant, have high affinity for SRBC, are nonspecific esterasepositive, are highly sensitive to hydrocortisone both in vitro and in vivo, and are devoid of receptors for the $\mathrm{Fc}$ portion of IgG or IgM. Tar cells respond to suboptimal doses of concanavalin $\mathrm{A}$ as well as to serum thymic factor but are unresponsive to phytohemagglutinin $\mathrm{P}$ or to pokeweed mitogen. Among them there is a subpopulation that binds peanut agglutinin $(26.9 \pm 2.0 \%)$ indicating their immaturity. These characteristics permitted us to differentiate Tar cells from $\mathrm{T} \gamma$ or $\mathrm{T} \mu$ cells. Functionally $\mathrm{T}$ ar cells are also peculiar because they participate in feedback inhibition and in the generation of suppression ${ }^{2}$ and are precursors of natural killer cells. ${ }^{3}$

In this paper we show that $\mathrm{T}$ ar cells are the responding cells in AMLR, in that their removal from total $T$ cells renders these irresponsive in AMLR. Also, purified $\mathrm{T}$ ar cells give significantly higher responses than do total $\mathrm{T}$ cells and their response increases linearly with increasing proportions of Tar cells. Conversely, Tar cells were found to have little or no role in the response in allogeneic mixed-lymphocyte reactions.

Our findings are in agreement with previous observations on the responding cells in AMLR. Thus, they have been determined to lack receptors for the $F_{C}$ portion of $\operatorname{IgG}(4,5)$, to be sensitive to hydrocortisone and responsive to concanavalin $\mathrm{A}(5-8)$, to be capable of generating suppression under concanavalin A stimulation $(7,8)$, and of generating natural (ytotoxicity $(9-11)$.

Peripheral blood MNC from systemic lupus erythematosus patients give low responses in $\operatorname{AMLR}(2,3,13)$. Accordingly, we have found quantitative and qualitative defects of circulating $\mathrm{T}$ ar cells in this disease. ${ }^{4}$

The AMLR is an interesting phenomenon that has both memory and specificity (15) and may reflect in vitro the operation of the immunoregulatory network. The finding of the responding cell in this system

\footnotetext{
${ }^{3}$ Palacios, R., D. Alarcón-Segovia, L. Llorente, A. RuízArguelles, and E. Díaz-Jouanen. Human postthymic precursor cells in health and disease. III. Autologous rosette-forming $\mathrm{T}$ cells are precursors of natural killer cells. Submitted for publication.

+ Palacios, R., D. Alarcón-Segovia, L. Llorente, A. RuízArguelles, and E. Fishbein. Human postthymic precursor cells in health and disease. II. Their loss and dysfunction in systemic lupus erythematosus and their partial correction with serum thymic factor. Submitted for publication.
} 
and the feasibility of its isolation may help further understanding of immunoregulation and of the diseases of man where aberrations of its network occur (16).

\section{ACKNOWLEDGMENT}

This work was supported in part by grant 1485 from the Programa Nacional de Salud, Consejo Nacional de Ciencia y Tecnología, Mexico City, Mexico.

\section{REFERENCES}

1. Opelz, G., M. Takasugi, and P. I. Terasaki. 1975. Autologous stimulation of human lymphocyte subpopulations. J. Exp. Med. 142: 1327-1333.

2. Sakane, T., A. D. Steinberg, and I. Green. 1978. Failure of autologous mixed lymphocyte reaction between $\mathrm{T}$ and non-T cells in patients with systemic lupus erythematosus. Proc. Natl. Acad. Sci. U. S. A. 75: 3464-3468.

3. Kuntz, M. M., J. B. Innes, and M. E. Weksler. 1979. The cellular basis of the impaired autologous mixed lymphocyte reaction in patients with systemic lupus erythematosus. J. Clin. Invest. 63: 151-153.

4. Katz, P., and A. S. Fauci. 1979. Autologous and allogeneic intercellular interaction: modulation by adherent cells, irradiation, and in vitro and in vivo corticosteroids. J. Immunol. 123: 2270-2277.

5. Wolos, A. J., and F. R. Davey. 1979. T-cell subpopulations in the autologous and allogeneic mixed lymphocyte reaction. Cell Immunol. 48: 415-419.

6. Ilfed, D. F., R. S. Krakauer, and R. M. Blaese. 1977. Suppression of the human autologous mixed lymphocyte reaction by physiologic concentrations of hydrocortisone. J. Immunol. 119: 428-434.

7. Sakane, T., and I. Green. 1979. Specificity and suppressor function of human $\mathrm{T}$ cells responsive to autologous non- $\mathrm{T}$ cells. J. Immunol. 123: 584-589.

8. Innes, J. B., M. M. Kuntz, Y. T. Kim, and M. E. Weksler. 1979. Induction of suppressor activity in the autologous mixed lymphocyte reaction and in cultures with concanavalin A. J. Clin. Invest. 64: 1608-1613.

9. Van de Stowe, R. A., H. G. Kunkel, J. P. Halper, and M. E. Weksler. 1977. Autologous mixed lymphocyte culture reactions and generation of cytotoxic T cells. J. Exp. Med. 146: $1809-1814$.

10. Jondal, M., and S. Targan. 1978. In vitro induction of cytotoxic effector cells with spontaneous killer cells specificity. J. Exp. Med. 147: 1621-1636.

11. Tomonari, K. 1980. Cytotoxic T cells generated in the autologous mixed lymphocyte reaction. I. Primary autologous mixed lymphocyte reaction. J. Immunol. 124: $1111-1121$.

12. Alarcón-Segovia, D., A. Ruíz-Arguelles, and L. Llorente. 1979. Antibody penetration into living cells. II. Antiribonucleoprotein IgG penetrates into $\mathrm{T} \gamma$ lymphocytes causing their deletion and the abrogation of suppressor function. J. Immunol. 122: 1855-1862.

13. Horwitz, D. A., A. C. Allison, P. Ward, and N. Knight. 1977. Identification of human mononuclear leukocyte populations by esterase staining. Clin. Exp. Immunol. 30: 289-298.

14. Alarcón-Segovia, D., and A. Ruíz-Arguelles. 1978. Decreased circulating thymus-derived cells with receptors for the $F_{c}$ portion of immunoglobulin $G$ in systemic lupus erythematosus. J. Clin. Invest. 62: 1390-1394.

15. Weksler, M. E., and R. Kozak. 1977. Lymphocyte transformation induced by autologous cells. V. Generation of immunologic memory and specificity during the autologous mixed lymphocyte reaction. J. Exp. Med. 146: 1833- 1838 .

16. Talal, N. 1978. Autoimmunity and the immunologic network. Arthritis Rheum. 16: 199-207. 